\title{
PRETREATMENT WITH GLABRIDIN PREVENTS CARRAGEENAN- INDUCED INFLAMMATION: THE ROLES FOR CYTOKINES AND OXIDATIVE STRESS PRODUCTION
}

\author{
ALI PARLAR ${ }^{1 *}$, EBRU ANNAÇ $^{2}$, SEYFULLAH OKTAY ARSLAN ${ }^{3}$, SALIHA AYŞENUR ÇAM $^{3}$ \\ ${ }^{1}$ Department of Pharmacology, Faculty of Medicine, University of Adiyaman, Adiyaman, Turkey \\ ${ }^{2}$ Department of Histology and Embryology, Faculty of Medicine, University of Adiyaman, Adiyaman, Turkey \\ ${ }^{3}$ Department of Pharmacology, Faculty of Medicine, University of Ankara Yildirim Beyazit, Ankara, Turkey
}

*corresponding author: parlar.ali@hotmail.com

Manuscript received: May 2020

\begin{abstract}
Inflammation is a natural response of the body's immune system to various external stimuli, in which the production of cytokines, nitric oxide, malondialdehyde (MDA) and myeloperoxidase (MPO) is enhanced. Glabridin is known for decreasing cell migration and increasing cGMP level. But so far, the anti-inflammatory effect of glabridin has not been proven histologically, and also its effect on oxidative stress parameters and cytokine levels has not been fully elucidated. The aim of this study, therefore, is to reveal possible mechanisms that can mediate the anti-inflammatory activity of glabridin. Animal groups were used including saline control, carrageenan, glabridin. Carrageenan was administered intraplantarly except for the saline control group. Paw thickness was measured at $0,1,2,3$ and $4 \mathrm{~h}$ which correspond to peak oedema times. MPO activity, MDA concentration, and glutathione (GSH) level in paw tissue for oxidant/antioxidant balance assessment were measured. Carrageenan increased the oedema, MDA, MPO, TNF- $\alpha$ and IL-1 $\beta$ production, which were abolished by glabridin. In the dermis and hypodermis, carrageenan caused an increase in inflammatory cells. Glabridin has played an important role in preventing peripheral inflammation, and in the near future, targeting the peripheral anti-inflammatory effect as a promising alternative to treat inflammation diseases may be considered a novel pharmacologic approach.
\end{abstract}

\section{Rezumat}

Inflamația este un răspuns natural al sistemului imunitar al organismului la diverși stimuli externi, în care sunt eliberate de citokine, oxid nitric, malondialdehidă (MDA) și mieloperoxidază (MPO). Glabridina este cunoscută pentru reducerea migrației celulare și creșterea nivelului de cGMP. Până în prezent, efectul antiinflamator al glabridinei nu a fost demonstrat histologic și, de asemenea, efectul său asupra parametrilor de stres oxidativ și a nivelurilor de citokine nu a fost complet elucidat. Scopul acestui studiu a fost evaluarea posibilelor mecanisme care pot media activitatea antiinflamatoare a glabridinei. Grupurile de animale luate în studiu au inclus: grupul control (ser fiziologic), grupul carrageenan şi grupul glabridină. Carrageenanul a fost administrat intraplantar animalelor, cu excepția grupului control. Grosimea labei a fost măsurată la $0,1,2,3$ şi 4 ore care corespund timpului maxim al edemului. Au fost determinate: activitatea MPO, concentrația MDA și nivelul de glutation (GSH) în țesutul labei pentru stabilirea statusului oxidativ. Carrageenanul a determinat creșterea edemului, precum și a MDA, MPO, TNF- $\alpha$ și IL-1 $\beta$. Nivelul acestor biomarkeri s-a redus semnificativ după administrarea glabridinei. Glabridina pare a avea un rol important în prevenirea inflamației periferice, iar în viitorul apropiat, poate fi o alternativă promițătoare pentru tratarea bolilor inflamatorii ca o abordare farmacologică nouă.

Keywords: glabridin, paw oedema, anti-inflammatory effect, cytokines, oxidative stress

\section{Introduction}

Inflammation is a natural response of the body's immune system to various external stimuli such as microorganisms, pathogens, trauma, stress, chemicals [1]. These mediators are mainly peptides, histamine, serotonin, nitric oxide (NO), cytokines such as tumour necrosis factor- $\alpha$ (TNF- $\alpha$ ) which are produced by macrophages, the interleukins (especially IL-1 and IL-6) and the leukotrienes [2-4]. The signs of oedema are redness, hypersensitivity, pain and swelling [5]. Therefore, swelling of the injured site may determine the severity of inflammation. Excessive pro-inflammatory production may induce various acute and chronic diseases such as rheumatoid arthritis, diabetes, asthma, cardiovascular diseases and even cancer [6]. Thus, in order to control the inflammation, several drugs have been assessed over centuries by scientific researchers such as nonsteroidal anti-inflammatory drugs (NSAIDs) [7], corticosteroids [8], cannabinoid 2 receptor agonist [9], immunosuppressive drugs [10] and even plant extracts [11]. However, excessive and long-term use of NSAIDs and corticosteroids may lead to many side effects such as gastrointestinal toxicity, addiction, drug resistance as well as Cushing syndrome [12]. As a result, active ingredients derived from plant extracts are getting popular among consumers in developing 
and developed countries due to less adverse effects and a relatively safer therapeutic profile [13].

Although there are many experimental inflammation models for research, carrageenan-induced paw oedema, resulting in vascular changes, oxidative stress with the increase lipid peroxidation or the depletion of antioxidant sulfhydryl pool such as glutathione, is the standard experimental model of acute inflammation, originally described by Winter et al. [1].

It has been demonstrated that Glycyrrhiza glabra, known as Licorice root, has been used to cure many diseases or symptoms such as cough, colds, asthma, chronic obstructive pulmonary disease, colds, peptic ulcers, gastritis, respiratory infections, chest diseases, liver diseases, disturbances of the intestine, stomach, indigestion, arterial diseases, urinary system diseases, urinary bladder diseases, kidney pain, expulsion of kidney stones, wounds and ulcers, eye diseases, fever, spasmodic pains of chronic gastritis, cancer and even oxidative stress and inflammation since very ancient times [14] because it contains many chemical substances, including saponin, flavonoids, isoflavonoids, stilbenoids and coumarins. Some of these chemicals consist of several active ingredients such as liqcoumarin, umbelliferone glycyrrhizin, liquiritic acid, dihydrostilbenes, glycyrretol, liquirtin, liquiritigenin and neoliquiritin glabridin, glabrone, glyzarin and galbrene [15]. Eventually, combining the above studies, for the last century, especially since the advance of science, although the pharmacological roles, especially antiinflammatory and antioxidant effects of these active ingredients have been revealed, there is little literature about the anti-inflammatory effect of glabridin and its mechanism of action. The aim of the current study was to investigate how glabridin influences oedema, the production of cytokine and oxidative stress occurrence in inflammatory processes.

\section{Materials and Methods}

\section{Chemicals}

Carrageenan and glabridin (98\% purity) were purchased from Sigma-Aldrich (USA) and Xi'an ZB Biotech Co., Ltd. (Shaanxi, Chine), respectively. Dimethyl sulfoxide (DMSO) was used as solvent for glabridin.

Experimental animals

Male Wistar-albino rats weighing $250 \pm 10 \mathrm{~g}$ were used in this study. The animals were provided from the Experimental Research Centre of Adiyaman University, Turkey. The ethical permissions for the study were taken from the Adiyaman University Animal Experiments Local Ethics Committee (Ethics Committee decision no. 2019/0014) where the study was conducted. Rats were randomly housed in appropriate cages at $22 \pm$ $2^{\circ} \mathrm{C}$ under a $12 / 12 \mathrm{~h}$ dark/light cycle with free access to tap water and commercial rat chow. Procedures were in accordance with the Guide for Care and Use of Laboratory Animals.

\section{Experimental Design}

After the rats were randomly divided into five groups of $6-8$ rats in each cage they were taken to the laboratory where the experiments were performed and four days were kept for acclimatization. The groups were: Saline Control, Carrageenan, Gla-10, Gla-20 and Gla-40, respectively. Carrageenan was administered intraplantarly to all animals, except the saline control group. Three days before carrageenan administration, Gla-10, Gla-20 and Gla-40 groups were treated with glabridin at a dose of 10,20 and $40 \mathrm{mg} / \mathrm{kg}$ b.w., respectively, for 3 days.

Carrageenan-induced paw oedema

This procedure has been used previously [9]. Briefly, inflammation was induced by giving an intraplantar injection of carrageenan $(100 \mu \mathrm{L}, 1 \% \mathrm{w} / \mathrm{v})$ into the paw. Oedema was expressed as the increase in paw thickness $(\mathrm{mm})$ after carrageenan injection relative to the pre-injection value for each animal. To measure the basal thickness, the paw was measured just before giving the carrageenan injection with electronic digital callipers and then after administering carrageenan, its thickness was measured at $0,1,2,3$ and $4 \mathrm{~h}$ which correspond to peak oedema time. The anaesthetized animals with ketamine $(50 \mathrm{mg} / \mathrm{kg}$ b.w., ip) and xylazine ( $5 \mathrm{mg} / \mathrm{kg}$ b.w., ip) were monitored for the loss of the tail reflex, which was defined as the loss of the twitching or movement of the tail pinched using the fingers. Blood was collected from vena jugularis and centrifuged at $3000 \mathrm{rpm}$ for $10 \mathrm{~min}$ to obtain serum. Serum samples were stored at $-80^{\circ} \mathrm{C}$ up to analysis. Animals were killed by neck dislocation and the paw tissue and skin samples were immediately taken for biochemical and histochemical analyses.

Measurement of malondialdehyde in paw tissue

As previously described, to determine the level of lipid peroxide, the concentration of malondialdehyde was measured in the paw tissue $[16,17]$. Briefly the tissue samples were homogenized in an ice bath, icecold TCA (trichloroacetic acid) by adding $10 \mathrm{~mL}$ of $10 \%$ TCA per $g$ of tissue, with an ultrasonic tissue homogenizer. After two consecutive centrifugations at 3,000 $\mathrm{g}$ for $15 \mathrm{~min}, 500 \mu \mathrm{L}$ supernatant was mixed with equal volume of $0.67 \%$ TBA (thiobarbituric acid) and heated to $100^{\circ} \mathrm{C}$ for $15 \mathrm{~min}$. The absorbances of the samples were then measured spectrophotometrically at $535 \mathrm{~nm}$. Each assay was performed in duplicate. Measurement of glutathione level in paw tissue As previously described, to determine the level of glutathione (GSH) was measured in the paw tissues [18]. Briefly, to the $0.5 \mathrm{~mL}$ of supernatant obtained by using the same homogenization procedure as described above, $2 \mathrm{~mL} 0.3 \mathrm{M} \mathrm{Na}_{2} \mathrm{HPO}_{4}$ solution was added. A $0.2 \mathrm{~mL}$ solution of DTNB (5,5'-dithiobis-2-nitrobenzoic acid) was added into the mixture, and the absorbance at $412 \mathrm{~nm}$ was measured immediately after vortexing. Each assay was performed in duplicate. 
FARMACIA, 2021, Vol. 69, 1

Measurement of myeloperoxidase activity in paw tissue

As previously described, the activity of myeloperoxidase (MPO) was measured in the paw tissues [19]. Briefly, exactly $100 \mathrm{mg}$ of tissue was weighed and homogenized in potassium buffer containing $0.5 \%$ hexadecyltrimethylammonium bromide (HETAB). In order to obtain the tissue pellet, homogenates were centrifuged at $4,500 \mathrm{~g}$ for $15 \mathrm{~min}$ at $4^{\circ} \mathrm{C}$ and then they were re-suspended, and the MPO activity was assessed by measuring the change in absorbance at $460 \mathrm{~nm}$ using o-dianisidinedihydrochloride and hydrogen peroxide. Each assay was performed in duplicate. One unit of MPO activity was defined as that degrading $1 \mu \mathrm{mol}$ of peroxide per min at $25^{\circ} \mathrm{C}$. The activity was then normalized as unit per mg of tissue (U/mg).

Measurement of cytokines levels in paw tissue $\mathrm{IL}-1 \beta$ and TNF- $\alpha$ levels were determined using ELISA kits. This process was performed 2 times, according to the procedures supplied by the manufacturer (Thermo Fisher Scientefic, Inc.) and the results were expressed as $\mathrm{pg} / \mathrm{mL}$ of serum.

\section{Histopathological procedures}

The rat paw tissues were preserved in $10 \%$ formaldehyde for fixation. At the end of the 5th day, fixed tissue samples were taken into plastic cassettes and exposed to routine histological follow-up steps consisting of chemical agents such as alcohol, xylene and paraffin. After these procedures were completed, the tissues were embedded in paraffin and thin sections $(5 \mu \mathrm{m}$ thick) were obtained using a microtome. The sections were deparaffinised in xylene and stained with Masson trichrome and toluidine blue stains. Sections were evaluated histopathologically using a light microscope (Carl Zeiss Axiocam ERc5 model) with digital camera. Statistical Analysis

All statistical analyses were carried out using GraphPad statistical software. All data were presented as mean \pm standard error mean. Difference between groups was compared using student $t$ test or one-way ANOVA followed by Tukey's Multiple Comparison. $\mathrm{p}<0.05$ was considered significant.

\section{Results and Discussion}

\section{Histopathological assessment}

\section{Saline control group results}

As illustrated in Figure 1, the epidermis composed of stratified keratinized squamous epithelium and dermis composed of irregular tight connective tissue have normal histological structure. The epithelial cells, connective tissue cells and connective tissue fibers had a normal appearance (Figures 1a and 1b). In the hypodermis, which is the deepest layer of the skin, components such as blood vessels, adipose cells showed a normal structure (Figure 1c). Additionally, mast cells density was normal in this group (Figure 1d).

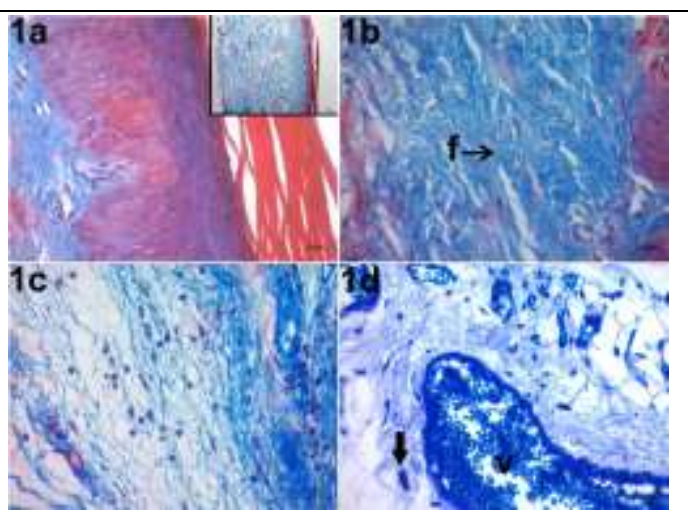

Figure 1.

Light microscopic images of tissue samples obtained from saline control group.

$1 \mathrm{a}$ - epidermis layer; $1 \mathrm{~b}$ - dermis layer; $1 \mathrm{c}$ - deep layer (hypodermis); $\mathrm{f}$ - connective tissue fibre; $\mathrm{v}$ - blood vessel; thick arrow - mast cell

(The objective for the magnification of images $40 \mathrm{x}-1 \mathrm{a}$, $1 \mathrm{~b}$ and $1 \mathrm{c}$ Masson trichrome staining and $1 \mathrm{~d}$ toluidine blue stain)

Carrageenan group results

As shown in Figure 2, in the skin samples of this group, the abundant inflammatory cells were observed in the dermis and hypodermis. It was also determined that the number of fibroblast cells in this group decreased and consequently decreased the density of connective tissue fibres. And also, oedema and haemorrhage were seen in this group (Figures $2 \mathrm{a}, 2 \mathrm{~b}$ and $2 \mathrm{c}$ ). An increase in mast cells was observed around the vessels in the hypodermis layer (Figure 2d).

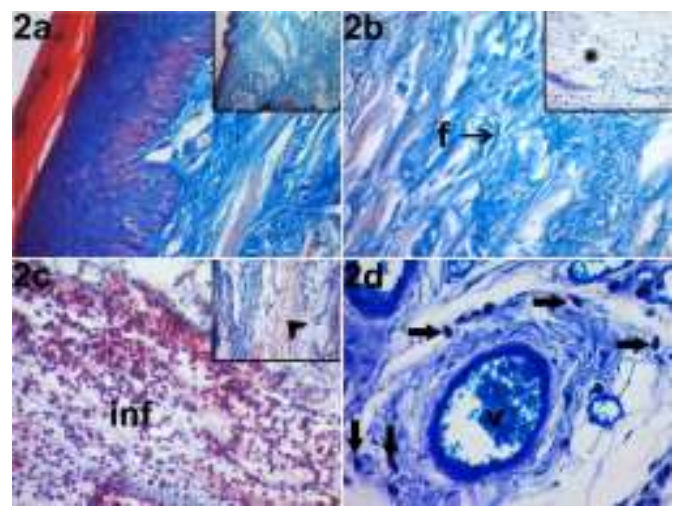

Figure 2.

Light microscopic images of tissue samples obtained from carrageenan group.

$2 \mathrm{a}$ - epidermis layer; $2 \mathrm{~b}$ - dermis layer; $2 \mathrm{c}$ - deep layer (hypodermis); $\mathrm{f}$ - connective tissue fibre; $\mathrm{v}$ - blood vessel; thick arrow - mast cell; inf - inflammation, star mark - oedema; arrow head - haemorrhage (the objective for the magnification of images $40 \mathrm{x}-2 \mathrm{a}, 2 \mathrm{~b}$ and $2 \mathrm{c}$ Masson trichrome staining and $2 \mathrm{~d}$ toluidine blue stain)

Gla10 group results

As illustrated in Figure 3, this group had a very similar appearance to the carrageenan group in the examination of the sections in term of epidermis, dermis, hypo- 
dermis layers and other tissue components (such as connective tissue fibres and connective tissue cells) (Figures 3a and 3b). It was not observed a decrease in inflammatory cell density compared to the carrageenan group (Figure 3c). As in the carrageenan group, numerous mast cells were seen around blood vessels in these specimens (Figure 3d).

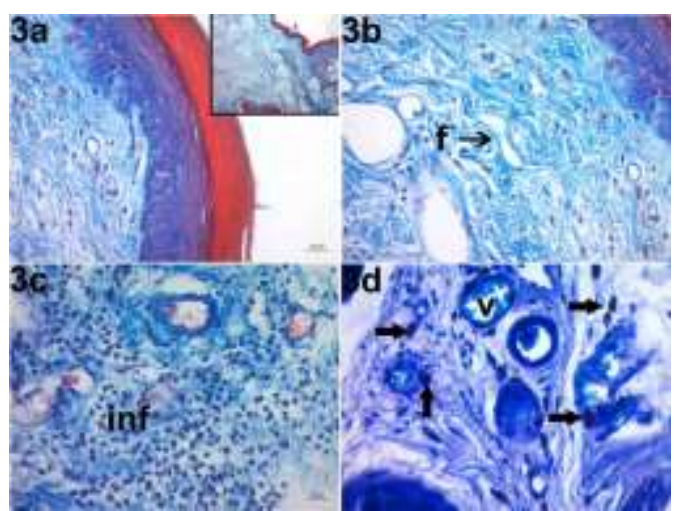

Figure 3.

Light microscopic images of tissue samples obtained from glabridin (10 mg/kg b.w.) treated group $3 a$-epidermis layer; $3 b$-dermis layer; $3 c-$ deep layer (hypodermis); $\mathrm{f}$ - connective tissue fibre; $\mathrm{v}$ - blood vessel; thick arrow - mast cell; inf - inflammation (the objective for the magnification of images $40 x-3 a, 3 b$ and $3 c$ Masson trichrome staining and $3 \mathrm{~d}$ toluidine blue stain)

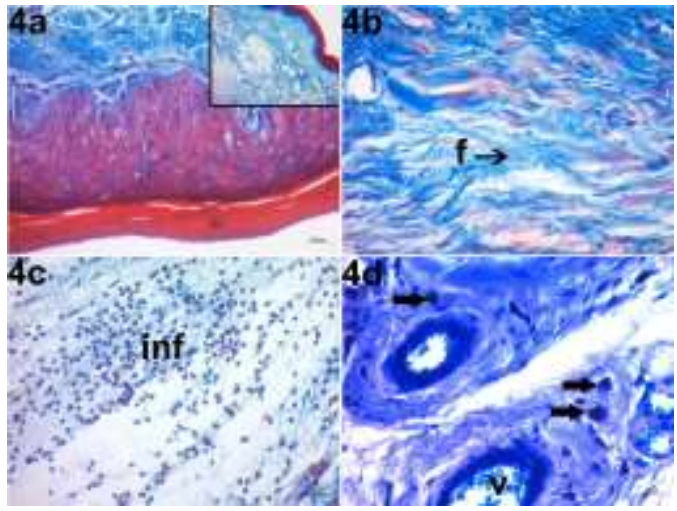

Figure 4.

Light microscopic images of tissue samples obtained from glabridin $(20 \mathrm{mg} / \mathrm{kg}$ b.w.) treated group $4 \mathrm{a}$ - epidermis layer; $4 \mathrm{~b}$ - dermis layer; $4 \mathrm{c}$ - deep layer (hypodermis); f - connective tissue fibre; $\mathrm{v}$ - blood vessel; thick arrow - mast cell; inf - inflammation. The inflammatory cells density in this group was smaller than that of the carrageenan group and gla 10 group (the objective for the magnification of images $40 \mathrm{x}-4 \mathrm{a}, 4 \mathrm{~b}$ and $4 \mathrm{c}$ Masson trichrome staining and $4 \mathrm{~d}$ toluidine blue stain)

Gla20 group results

The inflammation cells density at the examination of this group was less than the carrageenan and glabridin 10 group in the dermis and hypodermis layers. The use of intermediate concentrations of glabridin reduced the cellular infiltrates. In addition, carrageenan induced oedema was significantly decreased in this group
(Figures 4a, 4b and 4c). And also, mast cell density had decreased around blood vessels in the connective tissue (Figure 4d).

Gla40 group results

The tissue specimens in this group were similar to the ones observed in the saline control group. There was no significant difference in term of epidermis, dermis, hypodermis and other tissue components (such as connective tissue fibres and connective tissue cells) compared with the healthy animals (Figure 5a, 5b and $5 \mathrm{c}$ ). Using the higher concentration of glabridin eliminated the negative effects of carrageenan. As in the saline control group, mast cells density was normal (Figure 5d).

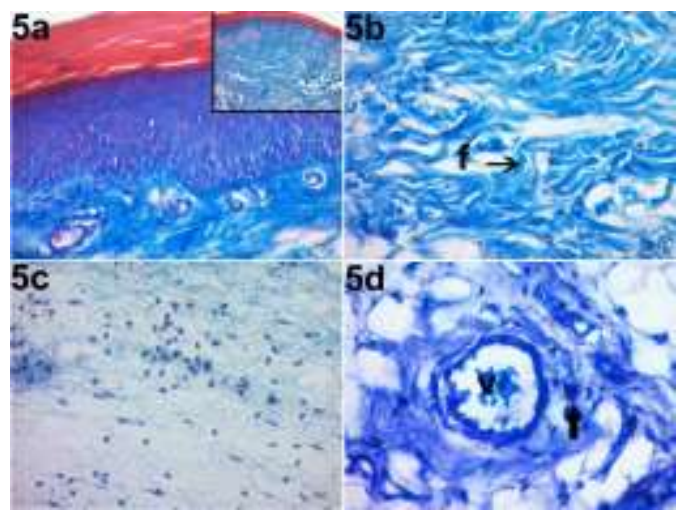

Figure 5.

Light microscopic images of tissue samples obtained from glabridin (40 mg/kg b.w.) treated group $5 \mathrm{a}$ - epidermis layer; $5 \mathrm{~b}$ - dermis layer; $5 \mathrm{c}$ - deep layer (hypodermis); $\mathrm{f}$ - connective tissue fibre; $\mathrm{v}$ - blood vessel; thick arrow - mast cell. There was a similar appearance with the control group. (the objective for the magnification of images $40 x-5 a, 5 b$ and $5 c$ Masson trichrome staining and $5 \mathrm{~d}$ toluidine blue stain)

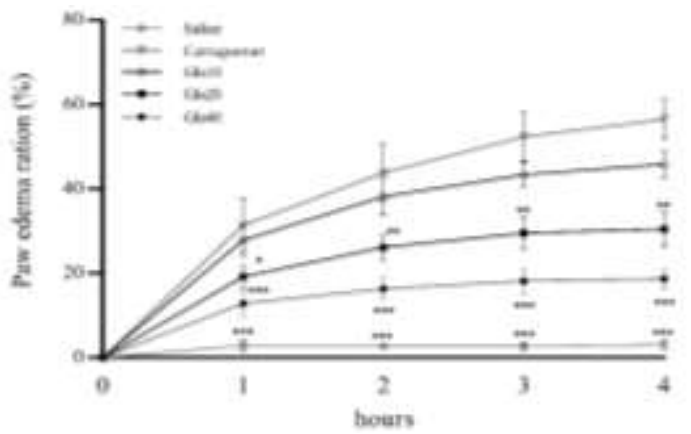

Figure 6.

Effects of glabridin on the carrageenan-induced paw oedema occurrence

Rats were evaluated for paw oedema at $0,1,2,3$ and $4 \mathrm{~h}$ post-carrageenan injection. Results were expressed as percentage of the increase in paw thickness. Each point represents the mean \pm SD of the six rats of each group.

* Statistically significant compared with the carrageenan group at $* \mathrm{p}<0.05 ; * * \mathrm{p}<0.01 ; * * * \mathrm{p}<0.01$ 
The effect on paw thickness of the carrageenaninduced paw oedema

As illustrated in Figure 6, the effect of carrageenan on rat hind paw thickness and the effect of glabridin on this thickness were tested. Carrageenan use significantly led to paw oedema when compared to saline groups ( $\mathrm{p}<0.001)$. But, the pretreatment with glabridin (20 or $40 \mathrm{mg} / \mathrm{kg}$ b.w.) caused attenuated carrageenan-induced paw oedema ( $<<0.001)$, while the pretreatment with $10 \mathrm{mg} / \mathrm{kg}$ b.w. dose of glabridin did not attenuate to the same extent the paw oedema $(\mathrm{p}>0.05)$.
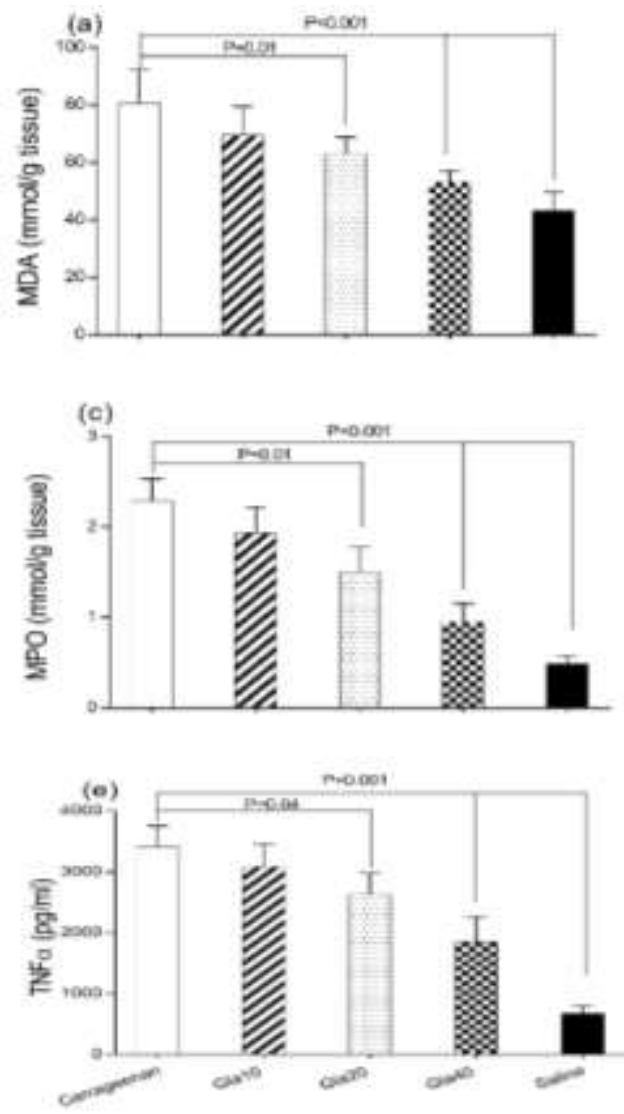

The MDA level in the carrageenan-induced paw oedema tissue

As shown in Figure 7a, carrageenan increased the MDA level in the paw tissue as compared to the saline group with the carrageenan group. Pretreatment with glabridin (20 or $40 \mathrm{mg} / \mathrm{kg}$ b.w.) caused attenuated carrageenan-induced paw oedema $(\mathrm{p}<0.05, \mathrm{p}<0.001$, respectively) while the pretreatment with $10 \mathrm{mg} / \mathrm{kg}$ b.w. dose of glabridin did not attenuate similarly the paw oedema $(\mathrm{p}>0.05)$.
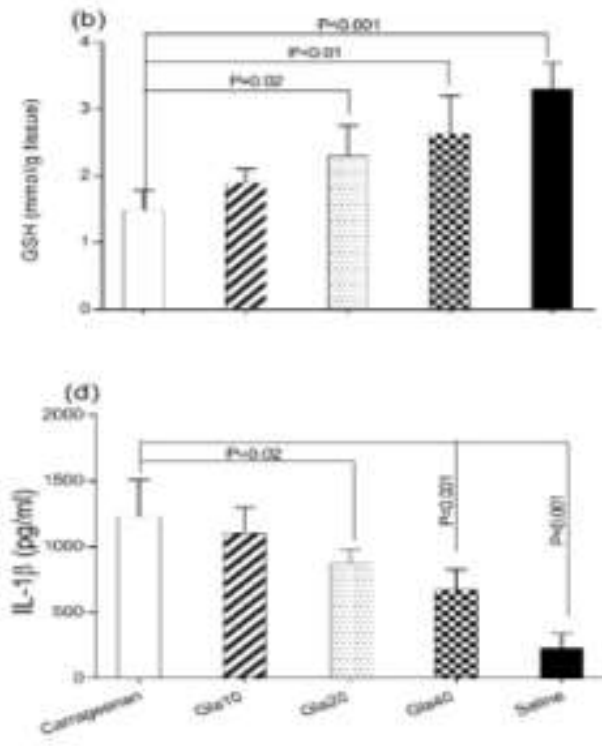

Figure 7.

The carrageenan-induced inflammation in paw tissue and the effect of glabridin on MDA (a), GSH (b), MPO (c), IL-1 $\beta(\mathrm{d})$, and TNF- $\alpha(\mathrm{e})$

Data are expressed as mean $\pm \mathrm{SD}(\mathrm{n}=6)$ and one-way ANOVA followed by Tukey's multiple range test. The $20 \mathrm{mg} / \mathrm{kg}$ b.w. dose of glabridin inhibited the oxidative stress markers in paw tissue and inhibited cytokines production in serum, $40 \mathrm{mg} / \mathrm{kg}$ b.w. dose of glabridin significantly led to the inhibition of oedema as compared to carrageenan treated group, but the lowest dose of glabridin was not statistically significant.

The level of GSH in the carrageenan-induced paw oedema tissue

As illustrated in Figure 7b, carrageenan decreased the GSH level in paw tissue as compared to saline group. The selection pattern for this biomarker was similar to MDA levels for studied groups.

The level of MPO activity in the carrageenan-induced paw oedema tissue

As shown Figure 7c, carrageenan increased the MPO activity in paw tissue as compared to the saline group.
Significant results were obtained for the groups pretreated with glabridin 20 or $40 \mathrm{mg} / \mathrm{kg}$ b.w. ( $\mathrm{p}=0.01$, $\mathrm{p}<0.001$, respectively).

The level of cytokines levels in serum

As illustrated in Figure 7d and 7e, carrageenan increased both IL- $1 \beta$ level and TNF- $\alpha$ level in rat serum when comparing to saline group with the carrageenan group ( $\mathrm{p}<0.001)$. The pre-treatment with glabridin $(20$ or 40 $\mathrm{mg} / \mathrm{kg}$ b.w.) caused decreased levels of both IL-1 $\beta$ and TNF- $\alpha$ in serum while the pre-treatment with 10 
$\mathrm{mg} / \mathrm{kg}$ b.w. glabridin did not attenuate similarly the IL- $1 \beta$ and TNF- $\alpha$ levels in serum.

One of the standard models of inflammation is carrageenan-induced paw oedema. Following to carrageenan injection, acute inflammation occurs within first few hours which consist of two phases. The first stage of inflammation is characterized by the release of neuro-mediators such as serotonin and histamine. The second stage is characterized by the release of prostaglandins. [20]. In this study, carrageenan model was used to determine whether glabridin improved oedema by modulating the level of cytokines and oxidative stress markers. The results of this study have shown that glabridin reduces serum cytokines levels such as IL- $1 \beta$ and TNF- $\alpha$ and improves oxidative stress markers such as MDA, GSH and MPO in carrageenan-induced paw oedema. However, higher doses of Gla, especially $40 \mathrm{mg} / \mathrm{kg}$ b.w., clearly decreased carrageenan-induced paw oedema and inflammation. Accumulating evidence has indicated that glabridin attenuates acute lung injury via calcium sensitive potassium $\left(\mathrm{BK}_{\mathrm{Ca}}\right)$ channels [21], but in our study, the anti-oedematous effect of glabridin maybe exerted via these channels. In a study by El-Ashmawy et al., it was shown that the anti-inflammatory effect of glabridin is via the downregulation of iNOS in rats with ulcerative colitis [22]. Moreover, they demonstrated that an imbalance between the generation of ROS and impaired antioxidant defence system results in oxidative stress. So, it maybe indicated that glabridin can reduce oxidative stress by improving the impaired antioxidant defence system.

The results of our previous study showed that glabridin inhibits phosphodiesterase, leading to increased intracellular cyclic guanosine monophosphate (cGMP), leading to increased intracellular protein kinase $G$ (PKG), in which glabridin activated the $\mathrm{BK}_{\mathrm{Ca}}$ channels both directly and indirectly, causing the cell hyperpolarization. The hyperpolarized cell was not affected by the harmful effects of ROS resulting from inflammation. In accordance with the results of our study, Dai et al. shows that NS-1619-induced oxidant production prevents ischemia/reperfusion-induced inflammation and mucosal barrier disruption in the small intestine by provoking increases in heme oxygenase-1 activity [23]. The other criteria for determining the extent of paw oedema is represented by measuring paw thickness. In the previous study, administering carrageenan caused a significant oedema in paw tissue [24, 25]. Consistent with previous findings, results of the present investigation also showed that, in carrageenan-injected rats, the total protein content in the paw tissue increased compared to the saline control group, whereas glabridin administration reduced the total protein content in paw tissue [26]. At the end of the histopathological examinations; it was found that there was a significant decrease in the number of inflammatory cells in the glabridin (20 and $40 \mathrm{mg} / \mathrm{kg}$ b.w.) and saline treated groups, although there was a large number of inflammatory cells in the tissue samples in the glabridin $(10 \mathrm{mg} / \mathrm{kg} \mathrm{b.w.})$ and carrageenan groups. As seen in the macroscopic analysis, glabridin reduced the epidermal thickness and the number of mast cells infiltrating skin lesions, leading to a reduction of macroscopic and histological ileum.

\section{Conclusions}

Eventually, combining the above studies, we discovered that glabridin has significant therapeutic effects on cytokines level and acute inflammation occurrence. Our experimental studies provided evidence to support the hypothesis that glabridin may have beneficial effects against inflammatory processes.

\section{Conflict of interest}

The authors declare no conflict of interest.

\section{References}

1. Winter CA, Risley EA, Nuss GW, Carrageenininduced edema in hind paw of the rat as an assay for antiiflammatory drugs. Proc Soc Exp Biol Med., 1962; 111: 544-547.

2. van Ryn J, Trummlitz G, Pairet M, COX-2 selectivity and inflammatory processes. Curr Med Chem., 2000; 7(11): 1145-1161.

3. Hunter CA, Jones SA, IL-6 as a keystone cytokine in health and disease. Nat Immunol., 2015; 16(5): 448-457.

4. Palomo J, Dietrich D, Martin P, Palmer G, Gabay $\mathrm{C}$, The interleukin (IL)-1 cytokine family - Balance between agonists and antagonists in inflammatory diseases. Cytokine, 2015; 76(1): 25-37.

5. Mert T, Sahin M, Sahin E, Yaman S, Anti-inflammatory properties of Liposome-encapsulated clodronate or Anti-Ly6G can be modulated by peripheral or central inflammatory markers in carrageenan-induced inflammation model. Inflammopharmacology, 2019; 27(3): 603-612.

6. da Rosa JS, de Mello SVGV, Vicente G, Moon YJK, Daltoé FP, Lima TC, de Jesus Souza R, Biavatti MW, Fröde TS., Calea uniflora Less. attenuates the inflammatory response to carrageenan-induced pleurisy in mice. Int Immunopharmacol., 2017; 42: 139-149.

7. Smith MJH, Ford-Hutchinson AW, Walker JR, Slack JA, Aspirin, salicylate and prostaglandins. Agents Actions, 1979; 9(5-6): 483-487.

8. Gentry C, Melarange R, Durie M, Moore G, Spangler $\mathrm{R}$, Effect of nabumetone, diclofenac, ibuprofen and an anti-inflammatory corticosteroid, dexamethasone, on cartilage metabolism in a biochemically-induced model of osteoarthritis. Clin Drug Investig., 1996; 11(1): 49-59.

9. Parlar A, Arslan SO, Doğan MF, Çam SA, Yalçin A, Elibol E, Özer MK, Üçkardeş F, Kara H, The exogenous administration of CB2 specific agonist, GW405833, inhibits inflammation by reducing cytokine production and oxidative stress. Exp Ther Med., 2018; 16(6): 4900-4908.

10. Guo J, Wang W, Yao L, Yan F, Local inflammation exacerbates cyclosporine a-induced gingival overgrowth in rats. Inflammation, 2008; 31(6): 399-407. 
11. Tao X, Ma L, Mao Y, Lipsky PE, Suppression of carrageenan-induced inflammation in vivo by an extract of the Chinese herbal remedy Tripterygium wilfordii Hook F. Inflamm Res., 1999; 48(3): 139-148.

12. Hodgson E, The effects of corticosteroids and nonsteroidal anti-inflammatory drugs, including aspirin, on coagulation. South African Family Practice, 2015; 57(5): 9-12.

13. Wang Y, Chen P, Tang C, Wang Y, Li Y, Zhang H, Antinociceptive and anti-inflammatory activities of extract and two isolated flavonoids of Carthamus tinctorius L. J Ethnopharmacol., 2014; 151(2): 944950.

14. Hussain H, Green IR, Shamraiz U, Saleem M, Badshah A, Abbas G, Rehman NU, Irshad M, Therapeutic potential of glycyrrhetinic acids: a patent review (20102017). Expert Opin Ther Pat., 2018; 28(5): 383-398.

15. Alwan AM, Nesrullah Z, Faraj E, Study the effect of ethanolic extract of Glycyrrhiza glabra on pathogenic bacteria. Int J Curr Microbiol App Sci., 2015; 4(5): 473-484.

16. Casini AF, Ferrali M, Pompella A, Maellaro E, Comporti M, Lipid peroxidation and cellular damage in extrahepatic tissues of bromobenzene-intoxicated mice. Am J Pathol., 1986; 123(3): 520-531.

17. Aktaş İ, Armağan İ, Investigation of the positive effects of silymarin on valproic acid-induced liver damage in rats. Adıyaman Üniversitesi Sağlık Bilim Derg., 2019; 5(2): 1445-1458.

18. Sedlak J, Lindsay RH, Estimation of total, proteinbound, and nonprotein sulfhydryl groups in tissue with Ellman's reagent. Anal Biochem., 1968; 25(1): 192-205.

19. Bradley PP, Priebat DA, Christensen RD, Rothstein $\mathrm{G}$, Measurement of cutaneous inflammation: Estimation of neutrophil content with an enzyme marker. J Invest Dermatol., 1982; 78(3): 206-209.

20. Bhukya B, Anreddy RNR, William CM, Gottumukkala $\mathrm{KM}$, Analgesic and anti-inflammatory activities of leaf extract of Kydia calycina Roxb. Bangladesh $J$ Pharmacol., 2009; 4(2): 101-104.

21. Chanda D, Prieto-Lloret J, Singh A, Iqbal H, Yadav P, Snetkov V, Glabridin-induced vasorelaxation: evidence for a role of BKCa channels and cyclic GMP. Life Sci., 2016; 165: 26-34.

22. El-Ashmawy NE, Khedr NF, El-Bahrawy HA, ElAdawy SA, Downregulation of iNOS and elevation of cAMP mediate the anti-inflammatory effect of glabridin in rats with ulcerative colitis. Inflammopharmacology, 2018; 26(2): 551-559.

23. Dai H, Wang M, Patel PN, Kalogeris T, Liu Y, Durante W, Korthuis RJ, Preconditioning with the BKCa channel activator NS-1619 prevents ischemia-reperfusioninduced inflammation and mucosal barrier dysfunction: roles for ROS and heme oxygenase-1. Am J Physiol Heart Circ Physiol., 2017; 313(5): H988-H999.

24. Parlar A, Arslan SO, anti-inflammatory effects of cannabinoid 2 receptor agonist, GW405833, in a model of carrageenan-induced acute inflammation of the rat paw. Int J Sci Res., 2019; 8(2): 55-58.

25. Parlar A, Arslan SO, Çam SA, Glabridin alleviates inflammation and nociception in rodents by activating BKCa channels and reducing NO levels. Biol Pharm Bull., 2020: 884-897.

26. Qamar W, Khan R, Khan AQ, Rehman MU, Lateef A, Tahir M, Ali F, Sultana S, Alleviation of lung injury by glycyrrhizic acid in benzo(a)pyrene exposed rats: Probable role of soluble epoxide hydrolase and thioredoxin reductase. Toxicology, 2012; 291(1-3): 25-31. 